\title{
Erratum to: Mapping of a gene that confers short lateral branching (slb) in melon (Cucumis melo L.)
}

\author{
N. Fukino $\cdot$ T. Ohara $\cdot$ M. Sugiyama \\ N. Kubo - M. Hirai - Y. Sakata - S. Matsumoto
}

Published online: 24 July 2012

(C) Springer Science+Business Media B.V. 2012

\section{Erratum to: Euphytica DOI 10.1007/s10681-012-0667-3}

Regrettably, an error was introduced in the last row of Table 3 of the above mentioned publication. The position of the QTL on LG XI (flanking markers CMAGN89 and ECM149) should have read 53.8-88.9 (instead of 16.6-39.7). The correct representation of Table 3 is published on the next page and should be treated as definitive by the reader:

The online version of the original article can be found under doi:10.1007/s10681-012-0667-3.

N. Fukino $(\bowtie) \cdot$ T. Ohara $\cdot$ M. Sugiyama

Y. Sakata $\cdot$ S. Matsumoto

NARO Institute of Vegetable and Tea Science,

Tsu, Mie 514-2392, Japan

e-mail: nbk@affrc.go.jp

N. Kubo $\cdot$ M. Hirai

Graduate School of Life and Environmental Sciences,

Kyoto Prefectural University, Seika,

Kyoto 619-0244, Japan

Present Address:

Y. Sakata

NARO Agricultural Research Center for Kyushu Okinawa

Region, Kurume, Fukuoka 839-8503, Japan 
Table 3 QTLs for lateral branching in $94 \mathrm{~F}_{2}$ plants derived from Nou-4 $\times$ Harukei-3, detected by using composite interval mapping

\begin{tabular}{llllllll}
\hline $\begin{array}{l}\text { Linkage } \\
\text { group }\end{array}$ & Flanking markers & Position ${ }^{\mathrm{a}}$ & $\begin{array}{l}\text { Threshold } \\
\text { LOD }\end{array}$ & $\begin{array}{l}\text { Maximum } \\
\text { LOD }\end{array}$ & $R^{2}$ b & $\begin{array}{l}\text { Additive } \\
\text { effect }^{\mathrm{c}}\end{array}$ & $\begin{array}{l}\text { Dominance } \\
\text { effect }^{2}\end{array}$ \\
\hline III & $\begin{array}{l}\text { ECTAMACA218 and } \\
\text { TJ10 } \\
\text { CMAGN89 and ECM147 }\end{array}$ & $6.0-18.8$ & 3.5 & 4.2 & 0.10 & 2.31 & -8.00 \\
XI & $53.8-88.9$ & 12.5 & 0.51 & -13.2 & 0.82 \\
\hline
\end{tabular}

${ }^{a}$ Expressed in Kosambi cM

b $R^{2}$ is the proportion of the phenotypic variance explained by the QTL

c Additive effects indicate an additive main effect of the parent contributing the higher-value allele. A positive value indicates that the higher-value allele (i.e., contributing to longer branches) came from Nou-4; a negative value indicate that the higher-value allele came from Harukei-3 